\title{
Palm Morphology and Anatomy ${ }^{1}$
}

\author{
T. K. Broschat ${ }^{2}$
}

Palms differ greatly from broadleaf (dicot) and coniferous (Gymnosperm) trees in their overall form and external structure (morphology) and in their internal structure (anatomy). Morphology and anatomy determine how palms grow, function, and respond to external and internal stress factors. This publication provides a basic understanding of how palms are constructed.

\section{Stems}

Palm stems (trunks) vary considerably in dimensions and appearance among species, but in general they are cylindrical to slightly tapered and occasionally bulging in shape (Fig. 1). The surface may be smooth to extremely rough and knobby and may be armed with sharp spines. Some species display prominent and often attractive leaf scars on their stems, which were points where leaves were attached to the stem. The spacing between these leaf scars (internodes) is a function of the rate of stem growth. Younger palms produce the longest internodes, which decrease sharply in length as the palm matures.

Stems of juvenile palms (those which have not yet achieved their maximum diameter) elongate very slowly, expanding incrementally in diameter with each new leaf. The result is that palm stem bases are V shaped, with the point of the $\mathrm{V}$ corresponding to the earliest stem tissue of the seedling (Fig. 2). Once a juvenile palm stem reaches its maximum diameter, substantial vertical elongation of the stem begins, and further stem diameter enlargement essentially ceases. The swelling observed at the base of the stem in mature specimens of some species is typically the result of new root development within the stem, although parenchyma cell enlargement or lignin deposition can also contribute to this swelling.

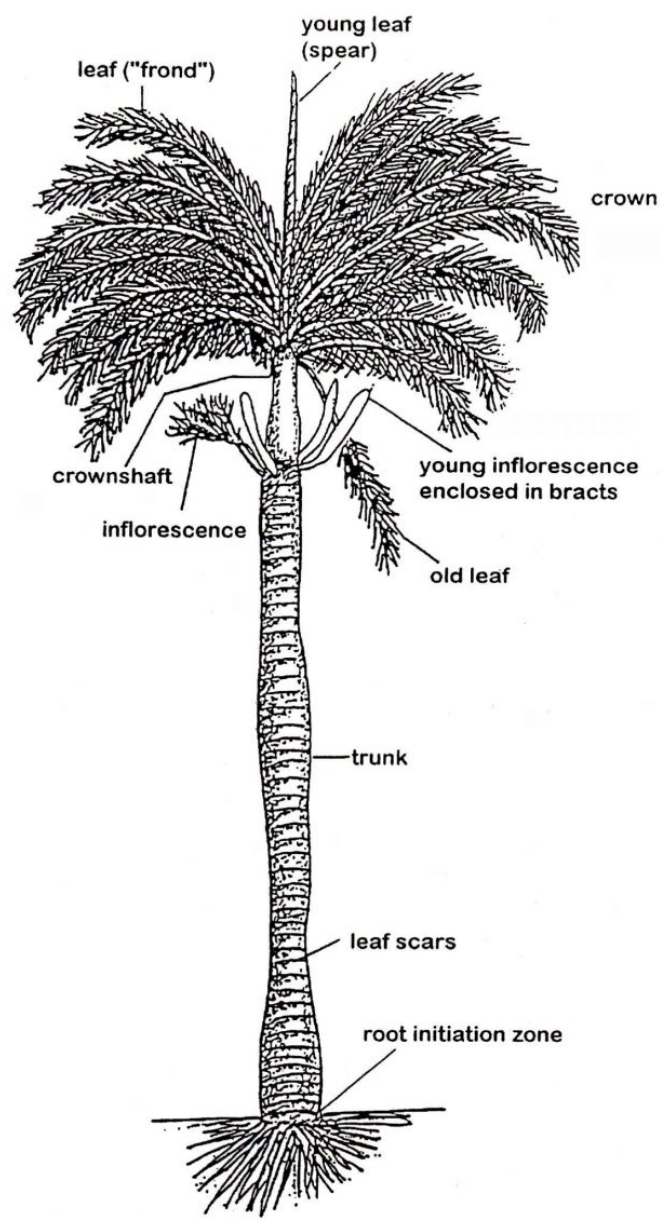

Figure 1. Generalized palm morphology. Credits: A.W. Meerow

1. This document is ENH1212, one of a series of the Environmental Horticulture Department, Florida Cooperative Extension Service, Institute of Food and Agricultural Sciences, University of Florida. Original publication date May 2013. Visit the EDIS website at http://edis.ifas.ufl.edu.

2. T. K. Broschat, professor, Environmental Horticulture Department, Fort Lauderdale Research and Education Center, Florida Cooperative Extension Service, Institute of Food and Agricultural Sciences, University of Florida, Davie, FL 33314 


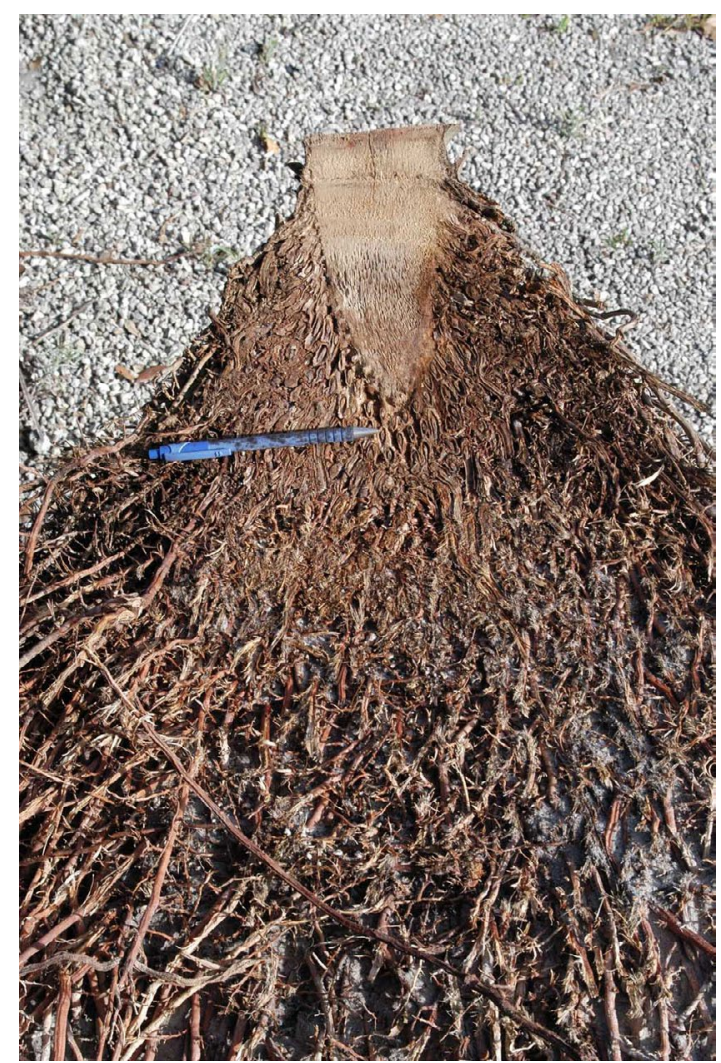

Figure 2. Longitudinal section through the stem-root interface of Phoenix roebelenii. Pen marks the soil level.

Credits: T. K. Broschat

Palms may be single stemmed or multi-stemmed (clustering) as a result of branching from axillary buds low on the stem. Only a few species (e.g., Hyphaene spp.) routinely exhibit aerial branching.

Palm stems are characterized by having a single apical meristem or growing point, which is also referred to as the bud or heart. All new leaves and flowers develop from the apical meristem (Fig. 3). It is surrounded by leaf bases, and, in species with a crownshaft, it is located near the crownshaft-stem interface. Palms have no lateral meristems or vascular cambium, which in dicot and coniferous trees produce additional xylem internally and phloem and bark externally. Death of the apical meristem in a palm results in the death of that stem in clustering species and death of the entire palm in single-stem species. It also means that stem wounds, which would eventually be compartmentalized and grown over in dicot trees, are permanent in palms.

Anatomically, palm stems are typical of monocots, with xylem (water-conducting tissue) and phloem (carbohydrate-conducting tissue) confined to vascular bundles scattered throughout the central cylinder of the stem. In most species, these bundles are concentrated near the periphery of the stem (Fig. 4). They are interspersed within a matrix of thin-walled undifferentiated parenchyma cells.

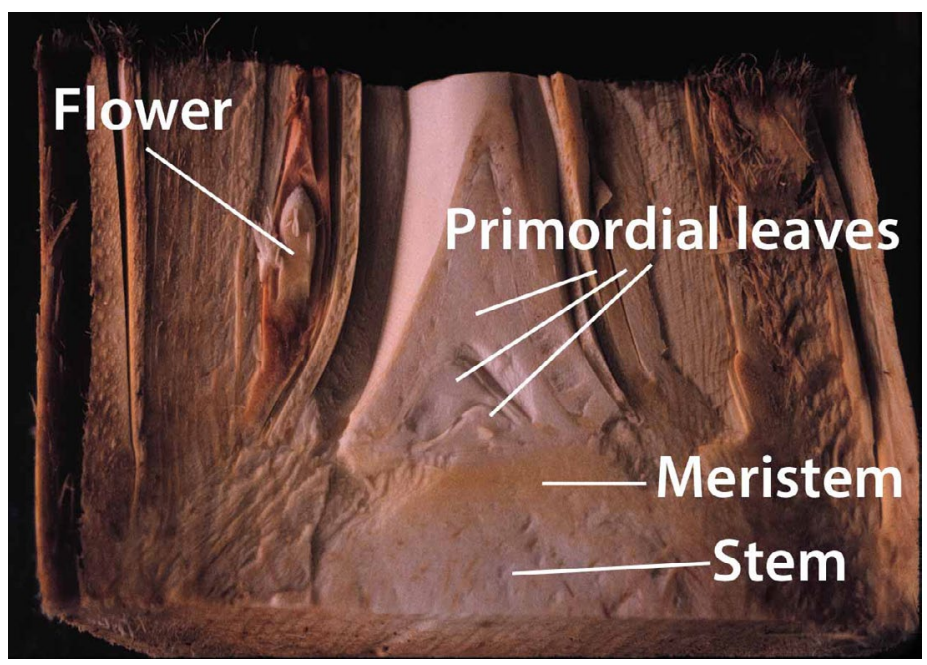

Figure 3. Cross section through stem of Sabal palmetto showing vascular bundles (dark spots) dispersed throughout a matrix of parenchyma cells (light background).

Credits: T. K. Broschat

Tomlinson (1990) describes palm trunks as analogous to reinforced concrete poles, with the vascular bundles equivalent to the steel rods and the parenchyma cells analogous to the concrete. Fiber cells adjacent to the phloem within the vascular bundles continue to deposit lignin and cellulose throughout their lives, thereby strengthening the oldest parts of the palm stem. In dicot and coniferous tree stems, the xylem vessel cells die and lose their contents before becoming functional as water-conducting tissue, and new phloem is continually being produced to replace the old. However, palm stem xylem, phloem, and even parenchyma cells remain alive for the life of the palm, which can be hundreds of years in some species (Tomlinson and Huggett 2012). To the outside of the central cylinder is a region of sclerified tissue known as the cortex and a very thin epidermis, which are sometimes collectively referred to as the "pseudobark."

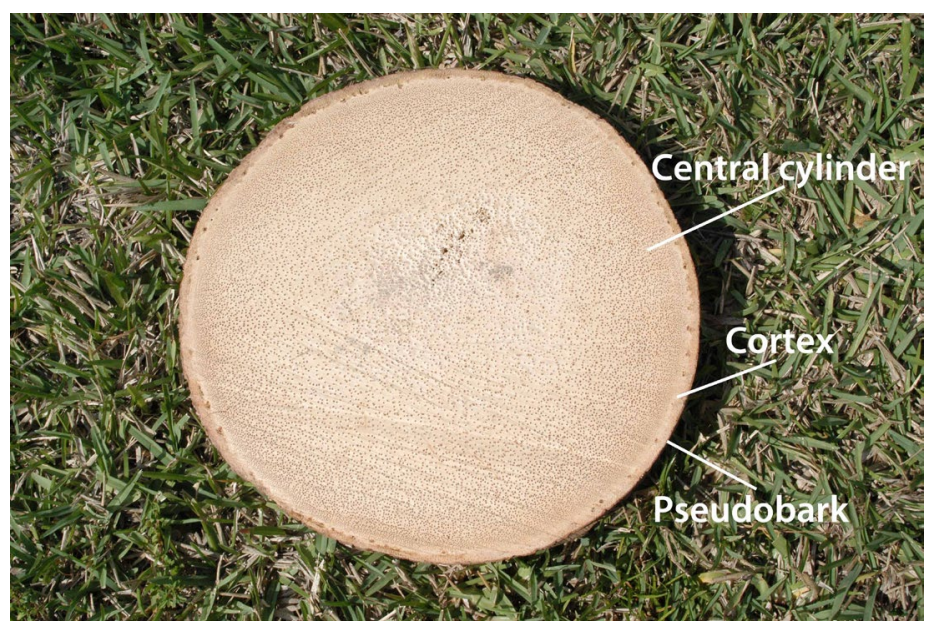

Figure 4. Longitudinal section through the meristematic region of Syagrus romanzoffiana showing meristem, primordial leaves and flowers, and stem tissue.

Credits: T. K. Broschat 


\section{Roots}

Palm roots differ greatly from those of broadleaf and coniferous trees in that they are all adventitious, emerging from a region of the trunk called the root initiation zone. Palm roots originate from the outer region of the central cylinder where they connect with vascular bundles in the stem. As they grow, the sheer volume of new roots may force the cortex and pseudobark to split and flare out from the base of the stem (Fig. 5). If new roots develop aboveground and come into contact with dry air, their development will be arrested until more favorable conditions are encountered. If soil or mulch is mounded around aerial root initials, they will resume their growth down into the soil. Palm roots emerge at their maximum diameter, and no additional increase in diameter will occur. Some primary roots may grow downward, but the majority grow laterally, extending out $50 \mathrm{ft}$. or more from the trunk in large specimens. If primary roots are cut, they may branch from behind the cut, but the resulting roots will be primary in their size and morphology. Secondary, tertiary, and even fourth-order roots are proportionately smaller in diameter and length, are short lived, and often grow upward toward the soil surface. These are the roots that absorb water and nutrients. Specialized roots called pneumatophores may literally grow upward and out of the ground in some species (e.g., Phoenix spp.). Palm roots do not have root hairs like dicot roots. Because they lack a cambium, roots of adjacent palms cannot graft, as they can in dicot trees.

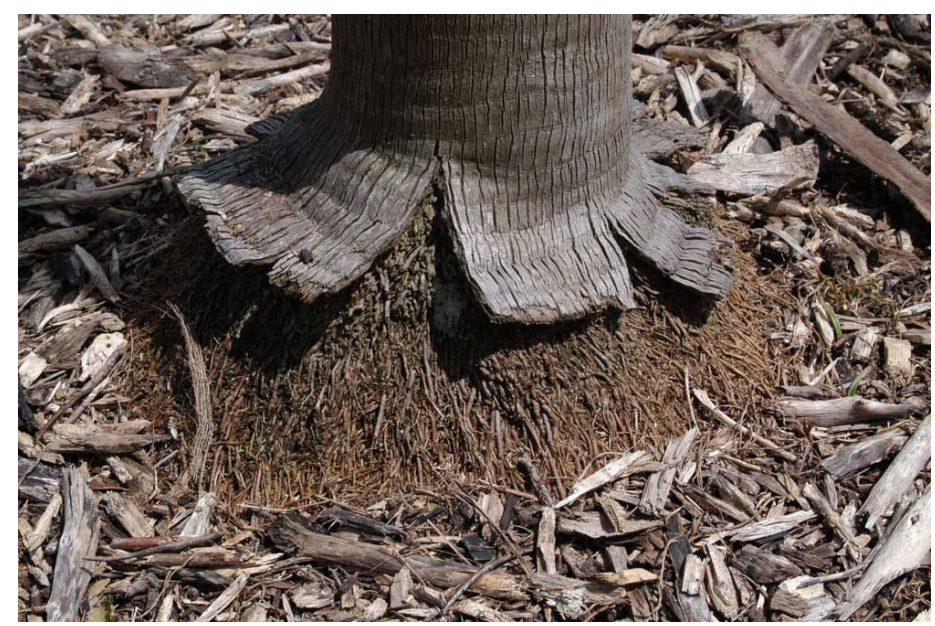

Figure 5. Split and flared cortex and pseudobark on Wodyetia bifurcata caused by emergence of new adventitious roots from the aerial portion of the root initiation zone.

Credits: T. K. Broschat

\section{Leaves}

The area of the palm where leaves are located is referred to as the crown or canopy. Palm leaves are generally of three types. Pinnate or feather-like leaves have leaflets entirely separated from each other and are attached perpendicularly to the rachis, an extension of the petiole into the leaf blade (Fig. 6). An example of a pinnate-leaved palm is the coconut palm. In palmate-leaved palms (fan palms), adjacent leaflets or leaf segments are joined laterally for some or most of their length. They originate from a single point at the tip of the petiole, which often includes a specialized protuberance called the hastula. Washingtonia palms are typical palmate-leaved palms. Costapalmate leaves are intermediate between pinnate and palmate leaves, with the overall leaf blade being round to oval in shape. Leaflets are joined together for some or most of their length but are attached along a costa, which is an extension of the petiole into the leaf blade. Sabal species have costapalmate leaves. A few other leaf shapes may also occur among palms. Some Chamaedorea species have bifid or two-lobed leaves, while Caryota species have bipinnate leaves. Palm leaflets are typically $\mathrm{V}$ shaped in cross section with the midvein at the apex of the V. Palm leaves with upright V-shaped leaflets are called induplicate, while those with an inverted $\mathrm{V}$ shape are called reduplicate.

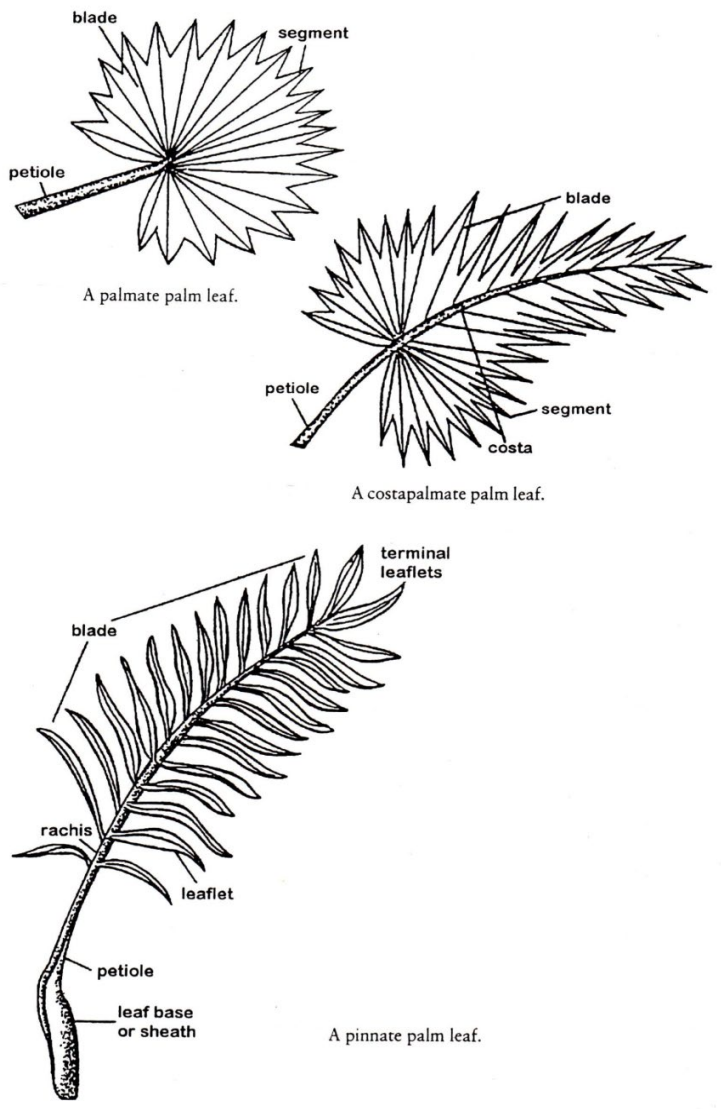

Figure 6. Parts of palmate, pinnate, and costapalmate leaves. Credits: A. W. Meerow 
Palm leaves typically have petioles of varying lengths, but some Copernicia species lack a petiole. All palm leaves are attached to the trunk by a flared leaf base. In some palms (e.g., Roystonea spp., Dypsis spp., etc.), the leaf bases are tubular and wrap around each other, forming a smooth, stem-like structure called a crownshaft.

\section{Flowers}

Flower stalks (inflorescences) arise within the leaf axils for most species of palms, but in those species having a crownshaft, inflorescences emerge from the stem just below the base of the crownshaft (Fig. 7). In a few hapaxanthic (palms that die after flowering) species, such as Arenga and Caryota, inflorescences develop from axillary buds throughout the length of the stem once the palm has transitioned from a vegetative to a reproductive state. In other hapaxanthic palms, such as Corypha or Metroxylon species, the inflorescence is terminal, being located above the canopy (Fig. 8). Developing inflorescences are typically ensheathed within a protective bract called a prophyll. The primary stalk of the inflorescence is known as the peduncle, with the first- and second-order branches called the rachis and rachilla, respectively. Both male and female flowers occur on monoecious palms, while dioecious palms possess only male flowers or female flowers.

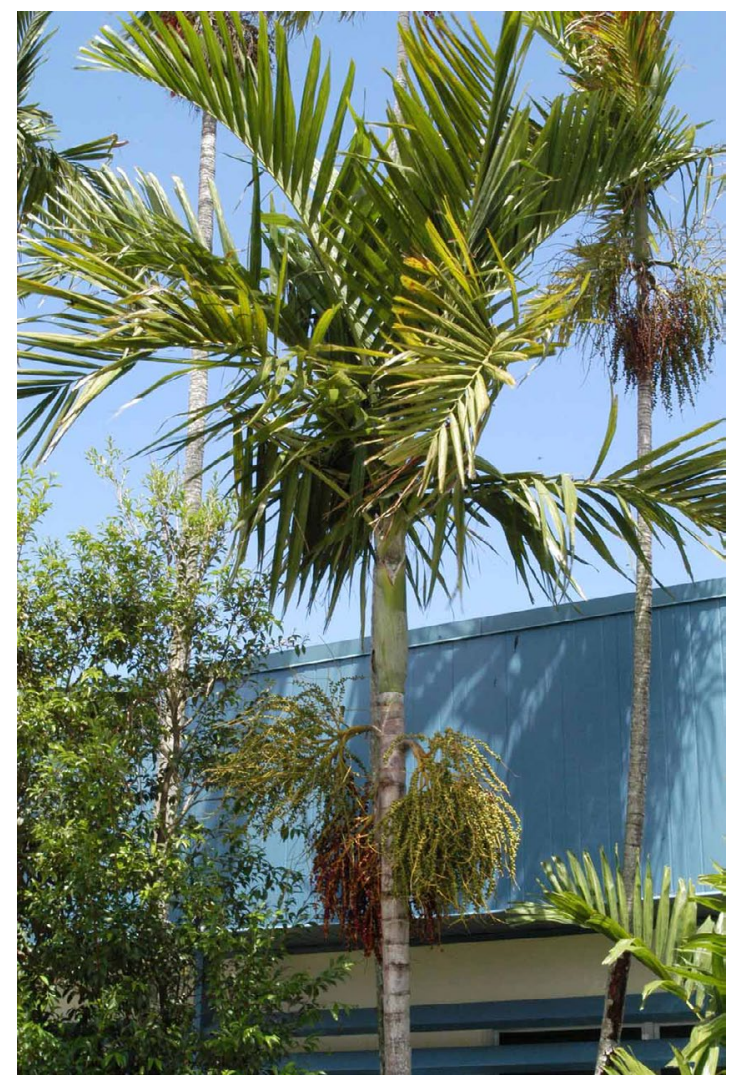

Figure 7. Inflorescences below the crownshaft in Ptychosperma elegans.

Credits: T. K. Broschat

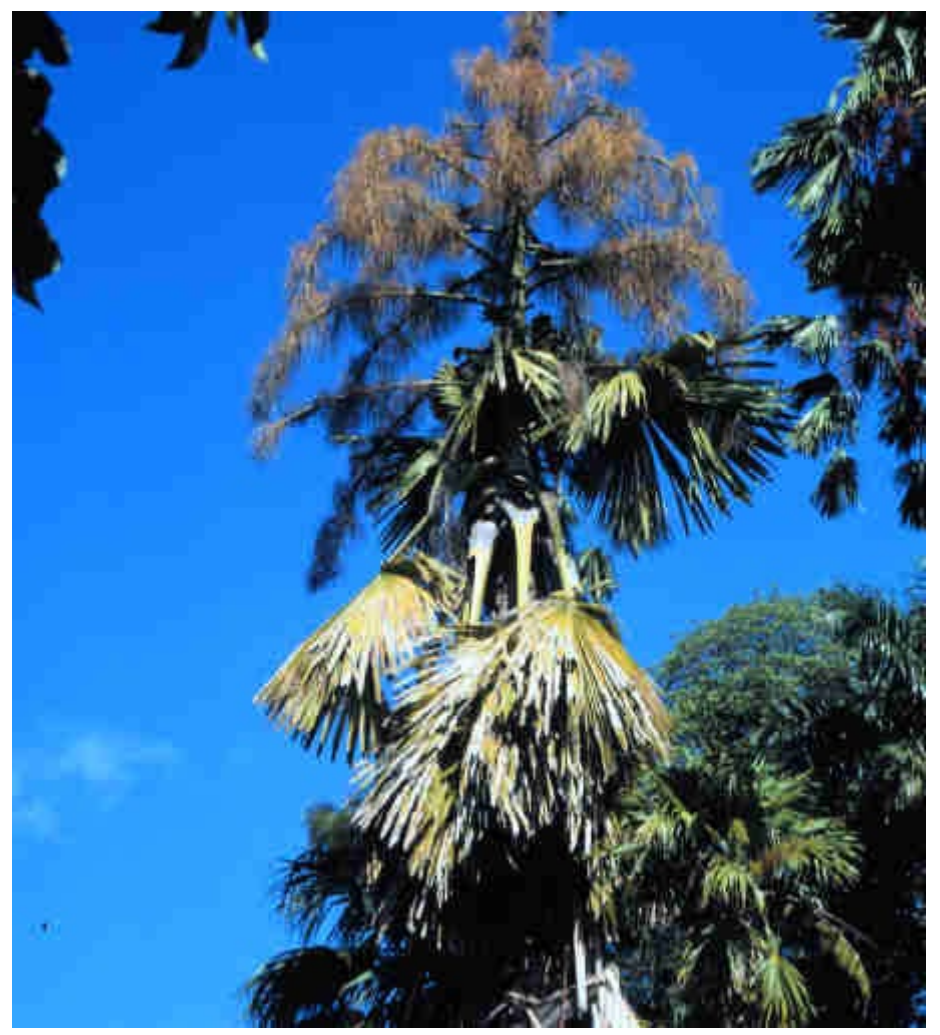

Figure 8. Terminal inflorescence in Corypha umbraculifera, a hapaxanthic palm.

Credits: T. K. Broschat

Palm fruits are botanically classified as drupes and have one or more stony seeds covered with a fleshy, mealy, or fibrous mesocarp and a thin superficial epicarp. The mesocarp of some species (e.g., Caryota, Arenga, Roystonea, Chamaedorea, etc.) contains needle-shaped calcium oxalate crystals that are extremely irritating to exposed skin. The stony outer layer of the seed is known as the endocarp, which encloses the food storage tissue (endosperm) and the embryo.

\section{References}

Tomlinson, P. B. 1990. The Structural Biology of Palms. Oxford, UK: Clarendon Press.

Tomlinson, P. B., and B. A. Huggett. 2012. "Cell Longevity and Sustained Primary Growth in Palm Stems." Amer. J. Bot. 99: 1891-1902. 